\title{
De levenslange gevangenisstraf *
}

\author{
W.F. van Hattum ${ }^{*}$
}

\section{Inleiding}

U herinnert zich misschien nog de berichtgeving over een schietpartij in 'Het Koetsiertje', een café in Delft, waarbij zes mensen werden gedood. De dader bleek van Turkse afkomst te zijn. Aanleiding was volgens hem geweest de opmerking dat hij 'misschien wel de Nederlandse nationaliteit had', maar 'geen Hollander was'. De verdachte kreeg levenslang. Het was 1983.

Mijn belangstelling voor het onderwerp 'levenslange gevangenisstraf' dateert van die tijd. Mijn eerste reactie op het vonnis was: 'zes mensen doodschieten, in een explosie, zonder motief, dat is niet 'normaal', en ook: 'een levenslange gevangenisstraf wordt opgelegd in het uiterste geval, ... is dit nu een voorbeeld van zo'n geval?' Vijftien jaar later ontmoette ik de 'Turk' van het Koetsiertje in de gevangenis Norgerhaven. Ik sprak hem in het kader van de bezoeken met studenten van de RUG. Zijn eerste vraag aan mij was of $i k$ wist hoe lang levenslang duurde. Het was een test.

Waarom hield die strafoplegging mij zo bezig? Omdat die ongewoon was. Omdat er sprake leek van een trendbreuk. Om de tijd te schetsen: in de jaren '70 van de vorige eeuw was niet eenmaal een levenslange gevangenisstraf opgelegd. Volgens gegevens van Justitie uit 1969 waren er sinds de Tweede Wereldoorlog 14 (commune) levenslange straffen uitgesproken. Alleen de beide laatstveroordeelden zaten op dat moment nog vast. De één was Hans van Z. die door de rechtbank Utrecht tot een levenslange gevangenisstraf

* Dit is de bewerking van een lezing gehouden voor het Lutje P.J.G. op 9 maart 2006 en voor het P.J.G. Oost Nederland op 8 juni 2006. Inmiddels is een uitvoeriger versie, met bronvermeldingen, met als titel 'De levenslange gevangenisstraf en de toevalsfactor' verschenen in $D D$ 2006, afl. 7/52, p. 755-776. De bronvermeldingen in noot 9, 11 en 14 zijn ten opzichte van die versie nieuw.

* Wiene van Hattum is UD straf- en strafprocesrecht aan de Rijksuniversiteit Groningen. 
was veroordeeld wegens drie roofmoorden. Hij begon net aan zijn lange detentie. De andere was 'dokter O.', de Berkelse arts die in het begin van de jaren 60 voor de tweede keer tot een levenslange gevangenisstraf was veroordeeld. Dokter O. had namelijk in de gevangenis in Leeuwarden Adri Lodder vergiftigd. O. en Lodder zaten daar beiden een levenslange gevangenisstraf uit wegens vergiftiging van hun vrouw, gepleegd in het begin van de jaren '50. De overige levenslanggestraften, 12 personen, waren anno 1969 inmiddels door middel van gratie in vrijheid gesteld of, zoals Lodder, overleden.

$\mathrm{Na}$ de milde jaren '60, afgemeten naar de mate van toepassing van gratie, en de milde jaren ' 70 , afgemeten naar de lengte van de opgelegde straffen, werd er in het begin van de jaren ' 80 voor het eerst sinds dertien jaar weer een levenslange straf opgelegd en zelfs tweemaal, kort na elkaar. De eerste keer betrof Koos H. (1982). H. werd veroordeeld voor drie levensdelicten. In 1983 volgde de tweede levenslange straf. Deze werd opgelegd aan de dader van de schietpartij in Het Koetsiertje (1983), hiervoor genoemd. De straf die aan Koos H. werd opgelegd, was mij niet zo opgevallen als die welke werd opgelegd aan de schutter van Het Koetsiertje. Ik denk nu dat dit te maken heeft met de snelle opeenvolging van twee levenslange straffen enerzijds en met het verschil in de aard en de omstandigheden van de beide zaken anderzijds. De snelle opeenvolging leek te duiden op een mogelijk drempelverlagend effect van de eerste levenslange straf. Het verschil tussen de beide zaken was echter groot: de dader van de schietpartij in het Koetsiertje had in het openbaar, in een eenmalige uitbarsting gehandeld; Koos $\mathrm{H}$. had in een tijdspanne van een paar jaar drie moorden gepleegd: de moord op twee jonge meisjes en op een jonge vrouw. Hij had hen planmatig ontvoerd, mishandeld en gedood. De kranten beschreven de gruwelijkste details. De verdachte ontkende elke betrokkenheid. Op al deze punten waren de beide zaken niet met elkaar te vergelijken en toch werd aan de schutter van Het Koetsiertje ook een levenslange gevangenisstraf opgelegd. Dat was - achteraf gereconstrueerd - de reden voor mijn aandacht én mijn verwondering.

In de jaren ' 80 werd nog een derde maal levenslang opgelegd en wel aan een Chinese man die in 1987 vier personen van een Chinese familie had gedood. Daarna was de levenslange gevangenisstraf geen muurbloempje meer in het arsenaal van de strafrechter: in de jaren ' 90 werd zij tenminste zevenmaal van stal gehaald en sinds 2000 - dus in zes jaar tijd - is de straf 20 keer opgelegd, waarvan zeven keer in 2005 en 2006. Dat is bijna evenveel als in 
bijvoorbeeld de periode 1896 tot 1940 . In die 44 jaar werden in totaal 22 personen tot levenslange gevangenisstraf veroordeeld. Vergelijken we de ernst van de delicten van nu met die uit bijvoorbeeld de jaren '70 dan kan niet gezegd worden dat de delicten toen minder aanleiding gaven tot 'levenslang'. Gedacht kan worden aan de treinkapingen in Wijster en De Punt, de gijzeling van de kinderen in de school in Smilde, de bezetting van het provinciehuis in Assen, steeds gepleegd door jongeren van Zuid-Molukse afkomst, of aan de moord en poging tot moord op politieagenten gepleegd in Utrecht door leden van de RAF. In geen van die gevallen werd de maximale straf opgelegd, ook niet toen er sprake was van herhaling (in de zaken van de Zuid-Molukkers).

Als gevolg van de hausse van levenslange straffen krijgen wij met een steeds groter aantal levenslanggestraften in de gevangenissen te maken; per 9 maart 2006 zijn het er 28. Vijftien van die straffen zijn definitief. Koos H., de Turk van het Koetsiertje en de Chinees zitten het langst, respectievelijk 24, 23 en 19 jaar. Het is goed om stil te staan bij de vraag wat wij aanmoeten met de tenuitvoerlegging en de eventuele beëindiging van deze straffen. Waar ik in deze bijdrage het accent op wil leggen, behoort echter tot de voorvraag, namelijk de vraag naar het bestaansrecht van de levenslange gevangenisstraf. Ik wil die vraag nu eens niet behandelen vanuit een puur juridisch perspectief, ${ }^{1}$ maar vanuit de rol van het toeval bij het opleggen van de straf. Toeval in de feiten maar ook toeval in de waardering van de feiten en van de schuld, waarbij de schuld staat voor het gedaan hebben en de mate van anders kunnen handelen, of toerekening. ${ }^{2}$ Deze invalshoek is mij ingegeven door de casus van Het Koetsiertje. Ik zou de stelling aan willen dat

de rol van het toeval bij de totstandkoming van de feiten waarover de rechter moet oordelen en het graduele karakter van opzet en schuld in de weg staan aan een absolute vorm van tenuitvoerlegging van levenslange straf.

1 Zie daarover W.F.van Hattum, 'Het irrationele van de levenslange straf. De levenslange gevangenisstraf in Nederland in het licht van de rechtspraak van het EHRM en andere Europese ontwikkelingen', in: Systeem in ontwikkeling, Liber amicorum G.Knigge (red. A. Harteveld, D.H. de Jong en E.F. Stamhuis), Nijmegen: Wolf Legal Publishers 2005, p. 231-259.

2 Mooij onderscheidt drie soorten schuld: de oorzaakschuld, de faalschuld en de verevenigsschuld. Ik doel op de eerste twee. A.W.M.Mooij, Schuld in strafrecht en psychiatrie, Deventer: Gouda Quint 1997. 
Met deze stelling wil ik geenszins suggereren dat er maar naar willekeur wordt gestraft. Het staat wat mij betreft buiten kijf dat gedragsdeskundigen en rechters die geroepen worden om in dit soort zeer ernstige zaken te oordelen, deskundig en naar eer en geweten hun vak uitoefenen en dat zij niet dan na zorgvuldige afweging tot een beslissing komen. Nee, ik wil de rol van het toeval en de vloeiende benadering van de menselijke psyche afzetten tegen de meedogenloosheid van de straf; meedogenloos, omdat zij, eenmaal onherroepelijk geworden, in beginsel duurt tot de dood erop volgt.

$\mathrm{Nu}$ speelt toeval in alle strafzaken een rol en is er bij de vaststelling van elk misdrijf sprake van een glijdende schaal waarop opzet en schuld worden bemeten. De hardheid van de levenslange straf maakt echter dat de rol van het toeval extra aandacht verdient en zelfs reden is om van het absolute karakter af te stappen.

Uit deze toelichting op de stelling mag wel blijken dat ik een voorstander ben van afschaffing van de levenslange gevangenisstraf in haar huidige vorm. Ik wil er meteen aan toevoegen dat ik tevens vind dat er een andere sanctie voor in de plaats moet komen die waarborgt dat gevaarlijke mensen die een zeer ernstig delict hebben gepleegd niet terugkeren naar de vrije maatschappij zolang het recidiverisico niet tot aanvaardbare proporties is teruggebracht. Ik denk daarbij aan een met een maatregel verlengbare straf. Ik heb dat elders uiteengezet. ${ }^{3}$ Deze met een maatregel verlengbare straf kan ook worden opgelegd in de gevallen dat geen TBS is opgelegd, bijvoorbeeld omdat de verdachte weigerde mee te werken aan het onderzoek of omdat de gedragsdeskundigen oordeelden dat sprake was van volledige toerekeningsvatbaarheid. Om de hierboven geformuleerde stelling te onderbouwen wil ik $\mathrm{u}$ een aantal feiten voorhouden, te weten: de verharding van het strafklimaat, de onduidelijkheid rond de duur van de sanctie, de diversiteit van zaken waarin een levenslange gevangenisstraf is opgelegd en welke rol het toeval daarin speelt, de regeling van de tenuitvoerlegging van de straf en de rol van gratie en de praktijk van die tenuitvoerlegging, zoals in het geval van de schutter van Het Koetsiertje. Ik rond af met een conclusie. 


\section{Het strafklimaat}

De toepassing van de levenslange straf kan gezien worden als een spiegel van ons huidige strenge strafklimaat. Goudsmit zou zeggen: 'we krijgen als samenleving de criminaliteit die we verdienen'. ${ }^{4}$ Met andere woorden: wij zijn met elkaar verantwoordelijk voor die criminaliteit. Ik voeg daar aan toe: en ook voor de straffen. Leggen we het verband tussen de welvaartsmaatschappij en het gebrek aan zorg voor sociaal zwakkeren zoals Van Tuinen ${ }^{5}$ en tussen de maatschappij en de toestand in de gevangenissen zoals Kelk ${ }^{6}$ dan moeten we concluderen dat het maatschappelijk draagvlak voor mensen met ernstige problemen niet groot is. De enige oplossing die wordt gevonden, is repressiever optreden: de strafmaxima worden hoger en straffen worden strenger. Harde cijfers laten zit zien. Tussen 1996 en 2003 zijn de onvoorwaardelijke vrijheidsstraffen met de helft toegenomen. Tussen 19952004 gingen we van 10.000 naar 16.000 gedetineerden, o.a. mogelijk gemaakt door het creëren van meerpersoonscellen; dat is van 66 naar 100 gedetineerden per 100.000 inwoners. Van 156 gestraften met straffen langer dan 12 jaar in 1997 gingen we naar 269 van dergelijke lange straffen in 2004, dat is een toename met $72 \%$. De plegers van ernstige delicten hebben vanuit dit gezichtspunt gezien eenvoudig de pech dat zij 'klimatologisch' in de opwaartse lijn zitten. Ter vergelijking citeer ik een stukje uit het vonnis van de rechtbank Assen in de zaak tegen de bezetters van het provinciehuis, tegen wie moord en gijzeling de dood ten gevolge hebbend bewezen was verklaard:

'Uit rapportage ... is komen vast te staan dat de daders in feite eenzame en gedesoriënteerde jonge mensen zijn, wier leven zich voltrok in een zeker isolement ... De psychiater constateerde bij ieder van de daders een ... leegte in de persoonservaring, een niet weten wie zij zijn, maar wel het behoefte hebben iemand te zijn, zelfs een belangrijk iemand te zijn.'

Deze persoonlijke omstandigheden liet de rechtbank meewegen bij de bepaling van de straf (15 jaar). De beschrijving van deze jonge mannen doet sterk denken aan de situatie van Mohammed B. Het is echter ondenkbaar dat deze

4 W.Goudsmit, 40 jaar 'lutje P.J.G.', een lutje geschiedenis, in: Ontmoetingen, Voordrachtenreeks van het Lutje P.J.G., nr.1, 1995, p. 20.

5 K.van Tuinen, 'Multi-functionele forensische centra binnen de geestelijke gezondheidszorg', in: Ontmoetingen, Voordrachtenreeks van het Lutje P.J.G., nr. 2, 1996, p. 28.

6 C.Kelk, 'Het gevangeniswezen in zwaar weer', $D D$ 2006, afl. 2, p. 101-110. 
overwegingen nu een rol bij de straftoemeting zouden hebben kunnen spelen.

Kenmerk van de huidige tijd is overigens niet alleen het zwaarder straffen maar ook het niet willen vergeven en vergeten. Ernstige feiten mogen bijvoorbeeld niet meer verjaren. Zo verliest de tijd haar uitwissende werking. Dit werkt door in het oordeel over de te geven invulling aan de levenslange straf. De levenslange straf 'moet in beginsel levenslang duren', zo wordt steeds vaker gehoord.

\section{Het 'misverstand' over de duur van de levenslange straf}

De wet bepaalt: 'Gevangenisstraf is levenslang of tijdelijk' (art. 10-1 Sr). Tijdelijke gevangenisstraf kan sinds kort worden opgelegd voor ten hoogste 30 jaar (art. 10-3 Sr). De huidige regeling van vervroegde invrijheidstelling (art. $15 \mathrm{Sr}$ ) maakt dat van deze straf tweederde deel ofwel 20 jaar moet worden ondergaan. Tot 1 februari 2006 was dit 13 jaar en vier maanden bij de toenmalige maximale tijdelijke gevangenisstraf van 20 jaar. Gevangenisstraf kan behalve tijdelijk ook levenslang zijn, zo bepaalt art. $10 \mathrm{Sr}$. Dat is dan tot het levenseinde ofwel tot de dood er op volgt. De wet bepaalt op welke delicten de levenslange straf staat. De rechter heeft in die gevallen steeds de keuze: een tijdelijke straf van maximaal 30 jaar of een levenslange straf. Dit alles afgezien van de mogelijkheid van TBS. Tot nog toe is dit niet mis te verstaan. De gevoerde gratiepraktijk zorgt echter voor verwarring.

\section{De rol van gratie sinds 1886}

De levenslange gevangenisstraf kwam in 1886 in het wetboek, in ruil voor de afschaffing van de doodstraf. Minister Modderman bepleitte de straf - het is inmiddels een veelvuldig aangehaald citaat - 'met bloedend hart', want, zo hield hij de Kamer voor: 'in beginsel deugt zij niet.' De minister vond dan ook dat voorwaardelijke invrijheidstelling op den duur tot de mogelijkheden zou moeten behoren. De straf werd bovendien ingevoerd in de wetenschap en met de bedoeling dat er altijd gratie kon worden verleend. Vanaf het begin was er dan ook sprake van een florerend gratiebeleid. Tot aan de Tweede Wereldoorlog werd iedere levenslang gestrafte na gemiddeld 17 jaar gegratieerd, tenzij de veroordeelde voor die tijd was overleden, met uitzondering van één die na 37 jaar in een krankzinnigengesticht overleed. Dit beleid is na 1945 niet gestopt, nee, zoals wij zagen: eerder geïntensiveerd. 
$\mathrm{Na}$ de oorlog was het beleid voor commune levenslanggestraften dat na 15 jaar gratie werd overwogen. In de praktijk werd de levenslange straf dus heter opgediend dan zij werd ten uitvoer gelegd. Hieraan hebben we het 'misverstand' te danken dat 'levenslang geen levenslang' is. Dit was tot in de jaren '90 zo'n wijdverbreid misverstand dat zelfs rechters niet op de hoogte waren van de werkelijke betekenis van artikel $10 \mathrm{Sr}$.

Tot in de jaren ' 70 werd het toen bestaande gratiebeleid niet alleen invulling gegeven maar ook uitgedragen. Het stond eenvoudig in de Kamerstukken. 'Tenuitvoerlegging tot de dood erop volgt', werd behalve inhumaan ook strijdig geacht met de resocialisatiedoelstelling zoals die in 1951 was neergelegd in de Beginselenwet Gevangeniswezen. Dat inzicht lijkt te zijn verlaten. Als nu aan de minister naar het gratiebeleid wordt gevraagd, bekruipt mij een gevoel dat hij het beleid bewust versluiert en dat hij er slechts op uit is de Kamer gerust te stellen met zijn antwoord: 'dat slechts één onherroepelijke veroordeling tot levenslange gevangenisstraf na 1 januari 1960 is omgezet in een tijdelijke vrijheidsstraf'. Dit is mogelijk een feitelijk juist gegeven, maar het is slechts de halve waarheid. De hele waarheid is een weergave van het gevoerde gratiebeleid vanaf de invoering van de levenslange straf tot heden met een overzicht van het aantal veroordelingen tot levenslange straffen en het jaartal. Dan zal ook blijken dat in de jaren ' 60 gratie werd verleend aan degene die vóór 1 januari 1960 werden veroordeeld. Deze gegevens ontbreken nu. Mijn conclusie is dat gratie in het huidig tijdsgewricht zo gevoelig ligt dat er liever over wordt gezwegen. Misschien wordt inderdaad zelfs in het geheel geen beleid meer toegepast, al kan die conclusie nog niet worden getrokken uit de huidige stand van zaken.

\section{De zaken waarin het afgelopen jaar levenslange gevangenisstraf werd opgelegd}

In het afgelopen jaar $^{7}$ is door zes verschillende rechtbanken zevenmaal levenslange gevangenisstraf opgelegd. Twee van deze vonnissen zijn inmiddels in hoger beroep voor wat betreft de straf bevestigd.

7 Geteld is van 11 maart 2005 tot 9 maart 2006. 


\section{De rechtbanken}

De rechtbanken legden in 2005 en 2006 levenslange gevangenisstraf wegens:

- moord op een medebewoner van de Pompekliniek door hem na een klap op het hoofd levend te begraven,

- roofmoord op een bejaarde vrouw en haar zwakbegaafde zoon, (in appel ook levenslang),

- moord en tweemaal poging tot moord op politieagenten bij aanhouding ter fouillering,

- uitlokking van brandstichting bij een Turks gezin in Eindhoven, waardoor twee buurjongetjes van de verdachte kwamen te overlijden en de ouders zwaar gewond raakten; de feiten werden gekwalificeerd als moord door middel van het medeplegen van brandstichting, (in appel ook levenslang),

- moord in het kader van een criminele organisatie door een Engelse huurmoordenaar, uit de Engelse gevangenis ontsnapt waar hij een levenslange straf voor moord onderging,

- de moord op Theo van Gogh, (Mohammed B.) en

- wegens moord op een zwerver, driemaal poging tot moord en 'beschadiging' van dieren (de Beul van Twente).

De zeven gevallen zijn dus heel divers. Uit deze zaken is niet af te leiden wat nu een specifiek geval is voor de oplegging van een levenslange straf.

De hoven en de hoge raad

Tussen maart 2005 en maart 2006 hebben de hoven in totaal vijfmaal een levenslange straf in tact gelaten (Den Bosch tweemaal, Den Haag tweemaal en Amsterdam eenmaal). De HR heeft twee cassatieberoepen verworpen waardoor in twee gevallen de straf definitief werd.

In twee gevallen is de levenslange straf alsnog in hoger beroep gewijzigd, en wel in een lange straf met TBS. In de zaak tegen Pascal F. werd de verdachte in hoger beroep van één van de twee in eerste instantie bewezen verklaarde moorden vrijgesproken. De overwegingen van het hof kwamen er kort gezegd op neer 'dat het opleggen van levenslange straf slechts in de meest uitzonderlijke gevallen dient te geschieden; dat de verdachte tot zijn 29e jaar geen noemenswaardig justitieverleden had en dat enigszins verminderde toerekeningsvatbaarheid niet kon worden uitgesloten.' Het redelijk schone strafblad en mogelijke verminderde toerekening hebben in deze zaak dus een rol gespeeld om - in tweede instantie - af te zien van de levenslange straf. 
Niet werd als reden genoemd dat in appel slechts één van beide ten als te gelegde moorden bewezen was verklaard, maar het zal ongetwijfeld ook een rol hebben gespeeld.

In de dubbele moord te Baarn werd door het hof net als in eerste aanleg door de rechtbank tweemaal moord bewezen verklaard en desondanks de sanctie aanzienlijk verlaagd. Het hof betrok in zijn overwegingen het overzicht van de advocaten Anker ${ }^{8}$ 'alsmede ruim honderd uitspraken van hoven waarbij (mede) ter zake van levensdelicten gevangenisstraffen van meer dan vier jaren werden opgelegd'. De feiten legitimeerden volgens het hof een zeer lange of zelfs levenslange gevangenisstraf, maar, aldus het hof, 'de verdachte leed aan een ernstig defect'. Een schizoïde persoonlijkheidsstoornis ontnam hem een normaal gevoelsleven en een normale toepassing van normen en waarden. Op het moment van vonniswijzing zou de stoornis niet behandelbaar zijn, maar door de geraadpleegde deskundige werd niet uitgesloten geacht dat door behandeling en bieden van structuur het recidiverisico aanmerkelijk zal verminderen. De feiten konden slechts in verminderde mate worden toegerekend. In deze zaak gaf 'het defect' waarschijnlijk de doorslag om af te zien van levenslange straf. Het strafblad - in 1971 was de verdachte wegens diefstal en afpersing tot straf en TBR veroordeeld en in 1980 en 1986 was hij voor dergelijke feiten alleen tot gevangenisstraf veroordeeld werkte zo gezien niet strafverhogend. In beide hier besproken zaken werd de beveiliging van de maatschappij gevonden in de TBS.

Vier gevallen waarin in eerste instantie geen levenslange straf is opgelegd, hoewel deze door het OM was gevorderd

Een vergelijking maken zoals het Amsterdamse Hof deed, is op zijn plaats. We zien overigens dat steeds meer gerechten dat zo expliciet doen. Ik noem nog vier gevallen uit 2005, waarin wel levenslange gevangenisstraf werd gevorderd maar niet werd opgelegd. De eerste is een gezinsdrama in Ruurlo. $\mathrm{Na}$ herhaalde bedreigingen aan hun adres schoot de verdachte zijn vrouw en zijn schoonmoeder dood; de feiten werden gekwalificeerd als moord maar waren de dader slechts in enigszins verminderde mate toe te rekenen. Het PBC deed geen uitspraak over het gevaar voor herhaling. Er was geen sprake van recidive terzake van levensdelicten. De rechtbank zag af van het opleggen van levenslange straf 'op grond van verdachtes traumatische verleden, zijn enigszins verminderde toerekeningsvatbaarheid, het ontbreken van een

8 Aan wie te danken is dat er een registratie is bijgehouden van de aantallen levenslanggestraften. 
oordeel over het gevaar van herhaling en de resultaten van haar onderzoek naar uitspraken in vergelijkbare zaken'. Er werd 20 jaar, zonder TBS, opgelegd. 'De rechtbank vindt weliswaar dat deze langst durende tijdelijke gevangenisstraf niet volledig voldoet aan hetgeen de verdachte heeft aangericht, maar ziet daarin nochtans geen aanleiding om de zwaarste, het zicht op terugkeer in de maatschappij benemende sanctie toe te passen.' Wat nu de doorslag gaf, blijft onduidelijk: de leeftijd, het traumatisch verleden, het ontbreken van recidive, de enigszins verminderde toerekeningsvatbaarheid, dat het een gezinsdrama was of nog iets anders? In elk geval was het niet de functie van de TBS, want die werd niet opgelegd.

De tweede zaak is een uitspraak van het Gerechtshof Leeuwarden, ook in een gezinsdrama (Appingedam). De verdachte stak zijn vrouw en schoonmoeder dood nadat hij zijn schoonvader zwaar lichamelijk letsel had toegebracht. Hij wilde daarop zijn vijf maanden oude zoontje om het leven brengen door hem te verdrinken. Eenmaal met het zoontje in het water van het Eemskanaal beland - zo vertelde de verdachte - was het 'ondiep' en kon hij 'gewoon staan'. De verdachte verklaarde verder dat hij 'Door kou bevangen' weer 'goed bij' kwam en 'wist dat hij niet goed bezig was'. Over de reden waarom zijn zoontje bij aanhouding - gewikkeld in een deken - op de achterbank van zijn auto lag, vertelde hij: 'Ik wilde hem naar het ziekenhuis brengen omdat hij nat en koud was en ben daarom richting Groningen gegaan'. Door het verloop van deze feiten nam de rechtbank vrijwillige terugtred aan bij de aangevangen poging tot moord op het kind. Bewezen werd moord, tweemaal gepleegd (op beide vrouwen) en poging tot moord (op de schoonvader). De persoonlijkheidsstoornis waaraan verdachte volgens de deskundigen leed, zou slecht te behandelen zijn; er zou gevaar voor recidive bestaan. De straf werd 15 jaar en TBS. Ook in deze zaak was een levenslange gevangenisstraf gevorderd. Het toeval zit hier naar mijn idee in het moment van aanhouding. Het is immers niet uit te sluiten dat de straf zwaarder zou zijn uitgevallen als de dader niet ná zijn sprong in het Eemskanaal maar daarvóór was aangehouden. De verdachte heeft in de extra tijd - die hem toevallig vergund was - kunnen laten zien dat hij nog 'mens' was.

De derde zaak is een gezinsdrama in Kerkrade, ook wel aan te duiden met 'de ex-marinier en de sportschool'. De dader doodde zijn ex-echtgenote, zijn zwager en zijn ex-schoonouders met wie hij in een relationeel en een zakelijk conflict was verwikkeld. Rechtbank en hof achtten een viervoudige moord bewezen. De feiten konden de verdachte volgens het hof slechts in 
sterk verminderde mate worden toegerekend als gevolg van een 'katathyme crisis'. In beide instanties werd 20 jaar en TBS opgelegd. De gevorderde levenslange straf werd afgewezen 'vanuit overwegingen van humaniteit', aldus toegelicht, dat 'ook bij de ernstigste misdrijven betekenis toekomt aan het inzicht dat de pleger van die misdrijven in beginsel perspectief moet worden geboden dat hij op enig moment weer in de samenleving zal kunnen terugkeren.' Deze overwegingen van het hof duiden erop dat dit humaniteitsprincipe de doorslag heeft gegeven om geen levenslange straf op te leggen. Daarnaast speelden echter ook de ernstige verminderde toerekenbaarheid en de behandelbaarheid een rol bij het bepalen van de sanctie, evenals het feit dat de verdachte niet eerder strafrechtelijk was veroordeeld.

Opmerkelijk is dat hetzelfde hof in de uitgelokte brandstichting in Eindhoven wel levenslang oplegde en het humaniteitsprincipe geen rol speelde. De verdachte in die zaak, op wiens initiatief de brand was gesticht, werd volledig toerekeningsvatbaar geacht, en had 'een relatief geringe justitiële documentatie'. Aan gevaar voor herhaling zijn in het arrest geen overwegingen gewijd. Het is vloeken in de kerk, maar ik noem de mogelijkheid toch: het toeval zat in de volledig andere samenstelling van de kamer van het hof.

Een andere verklaring is echter ook mogelijk. Op grond van de drie hiervoor besproken zaken namelijk - die zich alledrie afspeelden in de gezins- of familiesfeer - zou voorzichtig kunnen worden geconcludeerd dat zgn. familiedrama's buiten het bereik van levenslang vallen. En zo'n geval was 'Eindhoven' niet. Het verschil zit hem dan niet in de samenstelling van de kamer maar in het feit dat het geen familiedrama was. Gezins- of familiedrama's ontsnappen echter niet meer altijd aan de levenslange straf. In maart 2006 is een levenslange gevangenisstraf geëist en opgelegd aan de man in Zoetermeer die zijn vrouw en twee kinderen ombracht 'omdat zijn vriendin uit Polen op bezoek kwam'. Hoewel een gezinsdrama, toch levenslang. Het wordt een test-case voor de houdbaarheid van mijn signalering. De zaak is in hoger beroep. ${ }^{9}$

De vierde zaak waarin levenslang is gevorderd maar door de rechtbank niet is opgelegd, is die tegen Wik H., de Schiedammer parkmoord. De feiten stonden niet op zich zelf maar vormden onderdeel van een reeks van aanran-

9 In hoger beroep is de straf gewijzigd in 20 jaar en TBS. Gerechtshof 's-Gravenhage, 13 april 2007, LJN BA2902 
dingen, verkrachtingen en afpersingen. $\mathrm{H}$. werd in eerste aanleg veroordeeld tot 20 jaar en TBS en in hoger beroep tot 18 jaar en TBS. Er was door het OM levenslang geëist. De verdachte zat 'tegen sterk verminderd toerekeningsvatbaar' aan. Er werd rekening gehouden met een groot risico van herhaling. Een afweging waarom geen levenslange gevangenisstraf werd opgelegd ontbreekt in dit arrest. De reden is dat op de bewezen verklaarde feiten volgens de rechters geen moord opleverden maar doodslag en poging tot doodslag, en daarop staat nu eenmaal geen levenslange gevangenisstraf. Het 'toeval' zit hier naar mijn idee in de kwalificatie van verdachtes opzet. Het OM legde moord ten laste, daarvoor was dus in de ogen van het OM voldoende bewijs. De rechter oordeelde echter anders. Een andere rechter had het met het OM eens kunnen zijn.

Conclusie uit de gepresenteerde zaken van het afgelopen jaar

De gegevens uit hier gepresenteerde zaken ${ }^{10}$ vormen geen matrix voor de keuze tussen de ene (levenslang) en de andere (tijdelijke) straf. Dat was ook niet te verwachten. De waardering van de feiten, de inschatting van het opzet en de inschatting van de toerekenbaarheid of schuld zijn subjectief en liggen op een glijdende schaal. Ook de opvatting over de toepassing van de levenslange straf kan per rechter(s) zo verschillen dat dit de straftoemeting beïnvloedt, zie daarvoor het arrest inzake het gezinsdrama in Kerkrade. De enige lijn is te ontdekken, is dat gezinsdrama's een bijzondere categorie lijken te vormen. Aan deze categorie daders wordt over het algemeen geen levenslange gevangenisstraf opgelegd. Het zou interessant zijn te onderzoeken waarom in die gevallen kennelijk meer mededogen (of is het inlevingsvermogen?) met de verdachte bestaat.

Tegenover de genoemde subjectieve inschatting van de zaken, die in het ene geval tot een levenslange straf leidt en in het andere geval niet, staat een keihard verschil in gevolgen. Die gevolgen liggen niet zozeer in de wijze van tenuitvoerlegging van de straf maar gelden haar (on)eindigheid.

10 Ik wijs er nogmaals op dat de hier gepresenteerde zaken slechts een afspiegeling vormen van het afgelopen jaar; bovendien heb ik ook niet álle 'ernstige' zaken behandeld. Voor hardere conclusies is een uitgebreider onderzoek nodig. 


\section{De tenuitvoerlegging van de levenslange gevangenisstraf}

Vroeger werden langgestraften geselecteerd en bij elkaar in dezelfde inrichting geplaatst. Levenslang gestrafte mannen kwamen terecht in Leeuwarden. $\mathrm{Na}$ de invoering van de Beginselenwet gevangeniswezen in 1953 werden de levenslanggestraften gedetineerd in gevangenissen voor langgestraften. Sinds de invoering van de Penitentiaire Beginselenwet (1999) is ook strafduur geen plaatsingscriterium meer. Een en ander heeft tot gevolg dat levenslanggestraften nu verspreid worden over de verschillende inrichtingen en dat zij van de gewone gedetineerden qua regiem niet zijn te onderscheiden. Dat betekent dus ook dat er geen bijzondere zorg wordt verleend. Zij doen 'gewoon' met de andere gedetineerden mee volgens de algemeen geldende regels. ${ }^{11}$ Op dit moment betekent dat, dat zij als alle anderen de nadelige gevolgen ondervinden van de versobering van de regiems: minder dagprogramma, door de week om kwart over vijf op cel. Ook wordt niet principieel een uitzondering gemaakt voor plaatsing in een meermanscel, al is mij niet bekend dat levenslanggestraften daadwerkelijk in een meermanscel zijn geplaatst. Als de levenslang gestrafte gedetineerde geen verblijfsstatus heeft, ontbreekt een regeling om hem anders te behandelen dan andere ongewenst verklaarde of illegale vreemdelingen.

\section{De rol van gratie $n u$}

De enige manier om aan de straf te ontkomen, is als gezegd gratie. Gratie speelt daarom een allesoverheersende rol in het leven van deze gedetineerden. Gratie is echter een gunst en geen recht. Gratie is afhankelijk van het advies van rechter, van de inschatting van het recidivegevaar, maar ook van de publieke opinie, de te verwachten commotie. Zo werd het gratieverzoek van 'de Turk' van Het Koetsiertje na 19 jaar detentie onder meer afgewezen op grond 'dat ook nu nog nabestaanden van de slachtoffers grote moeite hebben met de acceptatie van het misdrijf.' De zaak wordt aangeduid als 'politiek gevoelig'.

Technisch juridisch gezien kan door middel van gratie de straf op jaren worden gesteld, zodat vrijlating op termijn plaatsvindt of per direct, maar de straf kan niet worden omgezet in TBS. Hoewel met voorwaardelijke gratie wel een situatie kan ontstaan die inhoudelijk op TBS lijkt, kan met gratie

11 Wel is een opvallende trend dat veel tot levenslange straf veroordeelden lange tijd in de EBI worden gedetineerd, hierover: Kirsten de Lange, doctoraalscriptie RUG, juli 2007. 
niet een rechtspositie worden bereikt die vergelijkbaar is met die van een gedetineerde aan wie TBS is opgelegd. Hij krijgt geen recht op een behandeling binnen een bepaalde termijn, geen recht op inzage in de stukken, op het horen van getuigen en het vragen van contra-expertise en een beslissing door een onafhankelijke rechter. Het 'verlengings'criterium is anders dan in de TBS volstrekt ondoorzichtig.

Zoals gezegd, ligt gratiering van levenslanggestraften kennelijk heel gevoelig. De minister heeft in 2004 slechts laten weten dat voor de afhandeling van gratieverzoeken van deze gestraften geen aparte afdeling meer bestaat; zij vormen, anders dan na de oorlog, geen aparte categorie meer. Dit betekent niet dat er een weloverwogen kentering is. De verandering is immers eenvoudig te verklaren door het inzakken van 'de markt' in en rond de jaren '70. Rechters houden dan ook nog steeds rekening met een bepaald gratiebeleid. Zo is het Haagse Hof in de zaak tegen Lucy de B. zelfs daarop vooruitgelopen bij het bepalen van de strafmaat. Dit is door de Hoge Raad afgestraft, maar de Hoge Raad houdt zelf ook rekening met een bepaald beleid. Bij de overname en omzetting van een levenslange straf uit het buitenland moet de rechter onderzoeken of de strafrechtelijke positie van de betrokkene niet wordt verzwaard. Daarbij moet hij volgens de Hoge Raad ook acht slaan op 'gegevens omtrent de door een instrument als gratieverlening gebruikelijkerwijs bepaalde feitelijke praktijk bij de tenuitvoerlegging van levenslange vrijheidsstraffen'. ${ }^{12}$ Wat betekent 'gebruikelijkerwijs' anders dan dat er een gebruik zou bestaan? De rechter bouwt echter op drijfzand en de gedetineerde zakt daarin weg. Ik zal dat laten zien aan de hand van het detentieverloop van de Turk van het Koetsiertje.

\section{De tenuitvoerlegging in de praktijk}

Omdat er momenteel slechts drie levenslanggestraften zo lang vast zitten dat zij op basis van het vroegere gratiebeleid in aanmerking zouden zijn gekomen voor een ambtshalve gratieoverweging, kan alleen op basis van het verloop van hun detentie iets over het huidige beleid worden gezegd. Van het verloop van de detentie van twee van hen heb ik enige informatie. 
Casus T.

Over de 'Turk' van Het Koetsiertje (overigens heeft hij de Nederlandse nationaliteit; hierna: T.) rapporteerde het PSC drie jaar na het begin van de detentie, in 1986, dat behandeling nodig was. T. werd echter in de Noorderschans in Winschoten geplaatst, in een soort afzondering dus. De verzoeken van T. om in aanmerking te komen voor behandeling werden afgewezen. Het PSC oordeelde in 1993 en 1996 dat een behandelsetting niet was aangewezen ' $n u$ de straf toch geen perspectief op vrijlating bood'. Het PBC oordeelde echter in 1999 in het kader van het gratieverzoek dat 'langdurige klinische behandeling noodzakelijk [was] ter beperking van het recidivegevaar'. Een paar opmerkingen in het psychiatrisch rapport over de houding van T. trokken mijn aandacht: '[T.] kan zich door behandeling te weigeren eindeloos gedetineerd houden' en '[T] stelt anderen die vinden dat de levenslange straf niet levenslang mag duren voor een probleem'. De beide zinnen geven m.i. precies weer voor welk dilemma de levenslange gevangenisstraf ons plaatst: de straf moet in naam duren tot de dood erop volgt maar in de praktijk moet dat niet want dat is niet menselijk. Regels om die praktijk te regelen, ontbreken echter. Het eindeloze karakter van de straf werd vervolgens aan $\mathrm{T}$. in de schoenen geschoven.

Het gratieverzoek van T. werd na de rapportage van het PBC afgewezen op grond van 'de gevoelens in de maatschappij en omdat klinische behandeling noodzakelijk is.' Deze afwijzing heeft twee jaar en 10 maanden op zich laten wachten. Het is waarschijnlijk vanwege de tweede overweging dat T. vanaf 2001 toch uiteindelijk in een behandelkliniek verblijft. Daar heeft hij, $o p$ basis van een afspraak tussen hem, zijn advocaat, de kliniek en het departement, de status van een TBS-gestelde. Op zichzelf is zo'n op maat gemaakte afspraak natuurlijk prachtig, maar het wettelijk kader ontbreekt en daarmee ook de tweejaarlijkse rechterlijke toets van zijn delictgevaarlijkheid en het recht op invrijheidstelling als de rechter van mening is dat verlenging niet langer noodzakelijk is, zoals wanneer werkelijk sprake was geweest van TBS. Dit gebrek aan rechtspositie staat in schril contrast met de door mij als toevalsfactoren aangeduide feiten in deze zaak. T. werd veroordeeld voor moord, eenmaal gepleegd, en doodslag vijfmaal gepleegd in voortgezette handeling en kreeg een levenslange gevangenisstraf opgelegd, zowel in eerste aanleg als in hoger beroep. Voor het opleggen van levenslange gevangenisstraf aan de verdachte hing veel, zo niet alles, af van de kwalificatie van het eerste schot en van de inschatting van de psychische toestand van de verdachte door de deskundigen. De kwalificatie was moord; dus kalm beraad 
en rustig overleg. Hoezeer dit oordeel juridisch houdbaar mag zijn, er waren ook argumenten om juist niet van voorbedachte rade te spreken. Deze konden echter minder goed aan het licht komen doordat de verdachte weinig wilde vertellen. Zo was er weinig bekend over de gebeurtenissen die enige tijd voor het delict een traumatische ervaring voor hem waren geweest. Mogelijk zou de meerdere informatie het oordeel dat sprake was van kalm beraad en rustig overleg hebben genuanceerd. In elk geval waren die gegevens van belang voor de inschatting van de toerekenbaarheid. De verdachte had zich echter zo ontoegankelijk getoond, dat het PBC oordeelde dat er geen conclusie over de toerekeningsvatbaarheid kon worden geformuleerd en beschouwde de verdachte daarom geheel toerekeningsvatbaar. Veel later oordeelde de psychiater van destijds dat met de kennis van nu een ander oordeel zou zijn geveld. Een belangrijke factor daarbij was het gebrek aan kennis van de culturele achtergrond van de verdachte. Zo speelden de traumatische ervaringen kort voor het delict een rol bij de gebeurtenissen en was er sprake geweest van druk die op de verdachte werd uitgeoefend om de familie-eer te beschermen. Ook het PBC is in 1999 teruggekomen op zijn eerdere oordeel. Twee contradeskundigen oordeelden overigens in $1983 \mathrm{al}$ dat de feiten in belangrijk verminderde mate waren toe te rekenen.

\section{Casus $C$.}

De tweede gedetineerde die ik wil opvoeren is de Chinees, hierna C. die sinds 1987 vast zit, dus 19 jaar. Hij zou zijn slachtoffers met respectievelijk 52 en 41 steken om het leven hebben gebracht en de kinderen de keel hebben doorgesneden. Roof zou het motief zijn geweest, maar veel is nog steeds onduidelijk. Het drama speelde zich geheel af in Chinese kring en C. heeft sinds zijn eerste bekentenis altijd ontkend de dader van de moordpartij geweest te zijn. Wel geeft hij toe dat hij op enige manier betrokken was. Zijn ontkenning zou de verklaring kunnen zijn waarom er geen TBS is opgelegd. Dat C.'s aandeel geringer is dan waarvoor hij werd veroordeeld, wordt door piw'ers die hem vele jaren van zeer nabij hebben meegemaakt, niet getwijfeld; zelfs de behandelend AG heeft, in het kader van de gratieprocedure, aan de juistheid van C.'s lezing niet meer willen twijfelen. ${ }^{13}$

13 Notitie inzake een gratieverzoek van C. uit 1996, aanwezig in het dossier van de advocaat van $\mathrm{C}$. 
C.'s gratieverzoek van 2002 is in 2004 - na twee jaar - afgewezen. ${ }^{14}$ In het kader van die beslissing verbleef C. in het PSC. Ook al luidde het oordeel van de medisch adviseur na afloop van dit onderzoek dat verdere tenuitvoerlegging van de sanctie 'medisch onverantwoord' moest worden geacht, bleef C. zitten waar hij zat, in een gewone gevangenis met een gewoon regiem. Dat betekent in zijn geval het regiem voor een ongewenste vreemdeling, zodat hij slechts cursussen Engels en Nederlands mag volgen, talen die hij goed beheerst en in beginsel uitgesloten is van alle andere opleidingen.

Naar aanleiding van de brief van de medisch adviseur heeft de advocaat bewerkstelligd dat diens conclusie nog eens werd onderzocht en wel door het PBC. Een van de vragen die aan het PBC zijn voorgelegd, luidt: in hoeverre de verergering van de psychische toestand van betrokkene hem kan worden aangerekend - door eigen in vrijheid gemaakte (en dus niet door de psychische stoornis beïnvloede) keuzes. Mij is niet bekend waarom juist die vraag werd gesteld, slechts dat die vraag zou zijn overgenomen uit het rechterlijk advies. De vraag lijkt te suggereren dat als C. er zelf voor kiest zich slecht te voelen, hij maar moet blijven zitten. Ook hier zien wij, net als bij T. dat de levenslanggestrafte voor het verloop van de tenuitvoerlegging van zijn straf verantwoordelijk wordt gesteld.

\section{Conclusie}

Uit de geschetste geschiedenis van twee tenuitvoerleggingen van levenslange gevangenisstraf blijkt het volgende. In beide zaken laten de vooruitzichten op gratie langer op zich wachten dan op grond van het naoorlogse beleid gewoon was. In de eerste zaak wordt na 18 jaar van weigering van behandeling toch aan resocialisatie gewerkt, in de tweede - ik zou haast durven zeggen wegens het ontbreken van een stoornis - nu na 19 jaar nog steeds niet. T. heeft enig houvast aan de gemaakte afspraak, C. kan nergens op rekenen. In de procedures zijn de veroordeelden afhankelijk van hoe de maatschappelijke wind waait. En die waait in de richting van levenslang opsluiten, dus tot de dood erop volgt. Het is momenteel niet duidelijk of de minister werkelijk voor zijn rekening wil nemen dat levenslanggestraften als straf - in hun cel sterven. De huidige opvattingen van de minister omtrent

14 Over de wijze van afdoening van dit gratieverzoek is met succes geklaagd bij de Nationale Ombudsman, rapport 2005/233, van 5 augustus 2005. 
gratie voor levenslanggestraften blijft tot op het laatste moment ondoorzichtig. Als tenuitvoerlegging tot het levenseinde echter werkelijk de bedoeling is van de levenslange straf zou dat een breuk betekenen met honderd jaar gratiebeleid. De detentie is dan te vergelijken met de vele onzekere jaren op deathrow. Dit element van de straf is zo inhumaan dat wij daar niemand aan bloot zouden moeten stellen. Te meer niet als een aantal toevalsfactoren of graduele, subjectieve beoordelingsfactoren hebben bijgedragen aan de keuze van de straf. 